\title{
Vyrų, sergančių obstrukcine miego apnèja, metabolinių ir uždegimo požymių ypatumai
}

\author{
Guoda Pilkauskaitè \\ LSMU MA Pulmonologijos ir imunologijos klinika
}

Šių metų rugpjūčio 28 d. Lietuvos sveikatos mokslų universiteto Medicinos akademijos (LSMU MA) viešame Medicinos mokslo krypties tarybos posėdyje buvo apginta Guodos Pilkauskaites daktaro disertacija pavadinimu Vyru, sergančiu obstrukcine miego apnejja, metaboliniu ir uždegimo požymiu ypatumai (biomedicinos mokslai, medicina). Mokslinis vadovas - prof. dr. Raimundas Sakalauskas, konsultantas - prof. dr. Skaidrius Miliauskas. Disertacija rengta 2008-2014 metais LSMU MA Pulmonologijos ir imunologijos klinikoje gavus Kauno regioninio biomedicininių tyrimų komiteto leidimą.

Pastaraisiais metais visame pasaulyje plačiai nagrinejjama obstrukcinès miego apnejos problema (OMA). Tai yra lètinè liga, charakterizuojama pasikartojančiais kvėpavimo sustojimo epizodais miego metu, lydimais epizodinès hipoksijos ir miego fragmentacijos. Patogeneziniai mechanizmai, siejantys OMA su širdies ir kraujagyslių ligomis, taip pat nutukimu bei metaboliniu sindromu, nèra aiškūs, dažnai persipynę, ypač dèl vèlyvos OMA diagnostikos. Iki šiol klinikinèje praktikoje OMA dažniausiai siejama su nutukimu ir mieguistumu dieną. Būtent nutukusiems mieguistiems pacientams dažniau nustatoma sunki OMA. Nutukimas pastaraji dešimtmetị tampa svarbia ne tik sveikatos, bet ir socialine problema, o mieguistumas dieną yra tiesiogine nelaimingu atsitikimu darbe ir vairuojant transporto priemones priežastis. Pasaulyje per retai OMA yra įtariama nenutukusiems, bet OMA simptomais besiskundžiantiems asmenims. Galbūt dèl šios priežasties OMA dažnai lieka nediagnozuota arba nustatoma jau išsivysčius metabolinèms ar kardiovaskulinėms komplikacijoms. Šie faktai skatina tyrinèti metabolinius ir uždegimo procesus sergant OMA. Gilesnis supratimas padètu anksti diagnozuoti ligą, tinkamai ją gydyti ir taip užkirsti kelią komplikacijų vystymuisi.

Šio darbo tikslas buvo ištirti ir įvertinti vyrų, sergančių obstrukcine miego apnejja, metaboliniụ ir uždegimo požymių ypatumus.

Tyrime dalyvavo vyrai, besiskundžiantys knarkimu. Tyrimo eiga parodyta paveiksle. Pacientu ịtraukimo ị tyrimą kriterijai:

- Lytis - vyras;

- Amžius - 25-65 metai;

- Anksčiau OMA nebuvo gydyta jokiais metodais;

- Nèra jokių lètinių ligu ar aktyvios infekcijos požymių.
Pacientų neįtraukimo ị tyrimą kriterijai (esant bent vienam iš nurodytų):

- Rūkymas;

- Priklausomybé nuo alkoholio ar kitu narkotikų;

- Psichikos ligos.

Tai pat tyrime galejo dalyvauti asmenys, kuriems:

- Nustatyta arterinè hipertenzija, tačiau gydoma ne daugiau kaip vienu vaistu nuo hipertenzijos;

- Nustatyti lipidu apykaitos sutrikimai, tačiau negydomi jokiais metodais.

Polisomnografijos tyrimu buvo patvirtinta arba paneigta OMA diagnozè. I tolesnę analizę neįtraukti pacientai, kuriems polisomnografijos tyrimu nustatytos kitos ligos, o ne OMA. Mieguistumas vertintas pagal Epworth mieguistumo skalès rezultatus. Tiriamiesiems nustatytas kūno masès indeksas (KMI), įvertinti visi metabolinio sindromo komponentai. Ištirtos uždegimo žymenų (didelio jautrumo $C$ reaktyviojo baltymo ir fibrinogeno) bei kraujagysliu adhezijos molekulių (tirpiụ kraujagyslių adhezijos molekulių-1 ir E-selektino) koncentracijos kraujo serume. Neutrofilų reaktyviụju deguonies formu vidutinis fluorescencijos intensyvumas nustatytas tèkmès citometrijos būdu. Endotelio funkcija buvo vertinta atlikus ultragarsinį endotelio funkcijos tyrimą žasto arterijoje, nustatant tèkmès sukeltą dilataciją.

Iš viso nagrinèti 102 tiriamụju duomenys: 20 knarkiančiu ir 82 sergančių OMA. OMA grupé reikšmingai skyrèsi nuo kontrolinès grupès pagal visus polisomnografijos kriterijus. Tiriamųjų amžius, kraujo įsotinimas deguonimi nemiegant tarp grupiu nesiskyrè. Sergantys OMA buvo labiau mieguisti ir skyrėsi nuo kontrolinès grupès pagal visus antropometrijos parametrus. Nè vienas kontrolinès grupès tiriamasis nebuvo nutukęs, nors buvo turinčių 


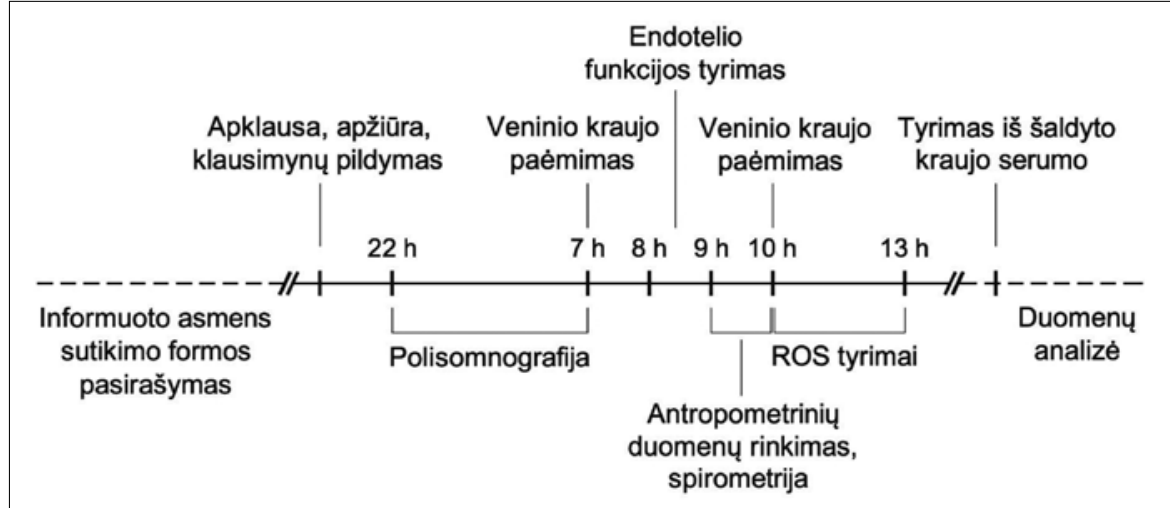

Pav. Tyrimo eiga

antsvorio. OMA grupeje 39 tiriamieji buvo nutukę, o 43 vyrų KMI neviršijo $30 \mathrm{~kg} / \mathrm{m}^{2}$.

Pradedant vykdyti ši tyrimą, mokslo literatūroje buvo plačiai diskutuojama apie uždegimo pokyčius OMA sergančiu asmenų organizme, gilinamasi i metabolinius procesus ir jų reikšmę lètinių ligų, kaip antai: širdies ir kraujagyslių ligos, cukrinis diabetas, patogenezejje. Ieškoma žymenų, kurie padètu kasdieniame klinikiniame darbe. Buvo akcentuojamas poreikis išsamesnių tyrimų, kurių rezultatai padètų atskirti galimai įtaką darančių veiksnių, t. y. amžiaus, lyties, nutukimo, ir pačios OMA itaką lètinių procesuc patogenezèje.

Nutukimas yra geriausiai ištyrinètas OMA rizikos veiksnys, kaip žinoma, glaudžiai susijęs su riebalų ir gliukozès apykaitos sutrikimais. Tyrimo vykdymo laikotarpiu vis plačiau imta nagrinèti ne tik OMA ryši su nutukimu, bet ir vertinti pilvini nutukimą ir visus metabolito sindromo (MS) komponentus kompleksiškai. İ šio tyrimo uždavinius ir protokolą buvo ịtrauktas MS sindromo vertinimas. Patogeneziniai mechanizmai, sukeliantys lètinị sisteminị uždegimą sergantiems OMA ir nutukusiems asmenims, yra gaudžiai persipynę. Tai dar vienas tyrimas, kurio metu ieškota sąsajų tarp OMA sunkumo ir uždegimo rodiklių, ịvertinus kūno masès įtaką.

Nors pastarąji dešimtmetị buvo plačiai kalbama apie OMA ir širdies ir kraujagyslių ligų sąsajas, tačiau tik tyrimo vykdymo laikotarpiu Europos ir Jungtinių Amerikos Valstijų rengiamose arterinès hipertenzijos diagnostikos ir gydymo rekomendacijose OMA buvo pripažinta nauja, dažna ir koreguojama antrinès arterinès hipertenzijos priežastimi [1].
Mokslo literatūroje gana plačiai tyrinètas oksidacinis stresas ir reaktyviųu deguonies formų (ROS) susidarymas sergant OMA ivvairiose periferinio kraujo ląstelèse, pvz.: limfocituose, monocituose. Nors gerai žinoma, kad neutrofilai aktyviai dalyvauja uždegimo procesuose ir gamina didelị kiekị ROS, tyrimų, vertinančių tiesioginị neutrofilų vaidmeni sergant OMA, atlikta nedaug, o jų duomenys prieštaringi. Šis tyrimas parodè, kad neutrofilu išskiriamas ROS kiekis buvo didesnis sergant sunkia OMA, palyginti su lengva ir vidutinio sunkumo liga, bet nesiskyrè nutukusių ir nenutukusių sergančių tokio paties sunkumo OMA grupèse [2]. Tai papildo žinias apie neutrofiluc itaką sisteminiam uždegimui sergant OMA, o kartu padeda įvertinti nutukimo vaidmenị.

Nèra vienareikšmio atsakymo apie kraujagyslių endotelio funkciją ir ivvairių kraujagysliu endotelio pažeidimo žymenų pokyčius sergant OMA. Pagal mokslo literatūroje kylančias diskusijas taip gali būti dèl negalejjimo atskirti, kuriuos procesus nulemia OMA, o kuriuos - gretutinès būklès. Tyrimo metu ypatingas demesys kreiptas i tiriamųjų atranką, izvertinant žinomus galimai ittaką darančius veiksnius. Nustatytas vidutinio stiprumo ryšys tarp KMI ir E-selektino bei tirpiųjų kraujagyslių adhezijos molekuliu -1 koncentraciju koncentracijų sergančiųjų OMA grupejje, o atmetus galimą KMI įtaką, nustatytas vidutinio stiprumo ryšys tik tarp tirpiųjų kraujagyslių adhezijos molekuliu -1 koncentraciju ir deguonies desaturacijos indekso. Šiame moksliniame darbe pateikiami rezul- tatai papildo iki šiol nustatytus duomenis ir suteikia išsamesnių mokslinių žinių apie metabolinius ir uždegimo pokyčius sergant OMA. Be to, buvo suformuluotos praktinès rekomendacijos. Rekomenduota, kad net ir nenutukę pacientai, kuriems nustatyta OMA, būtų tiriami, ìvertinant visus MS komponentus. Taip pat visiems nutukusiems asmenims esant ar nesant MS reikètų ìvertinti OMA riziką. Jei ji yra, pacientai turètų būti siunčiami tirti ir gydyti. Ankstyva diagnostika ir tinkamas laiku pradètas gydymas padètú išvengti širdies ir kraujagyslių ligų komplikacijų, kartu užkirstų kelią nelaimingiems atsitikimams, kuriuos patiria OMA sergantys asmenys.

Tyrimo tema buvo parengta literatūros apžvalga, publikuoti du moksliniai straipsniai tarptautiniuose žurnaluose, turinčiuose citavimo indeksa $[2,3]$. Be to, tyrimo duomenys buvo pristatyti mokslinèse konferencijose Lietuvoje bei užsienyje.

Darbo autorè yra dèkinga visiems Pulmonologijos ir imunologijos klinikos mokslininkams ir pedagogams už galimybę atlikti ši darbą bei vertingas pastabas, Miego laboratorijos bendrosios praktikos slaugytojoms už pagalbą vykdant ši tyrimą, Kardiologijos klinikos gydytojams Raimondai Verseckaitei ir Tomui Lapinskui, vadovaujamiems prof. habil. dr. Renaldo Jurkevičiaus už endotelio funkcijos tyrimus, Laboratorinès medicinos klinikos vadovei prof. dr. Astrai Vitkauskienei ir darbuotojoms gyd. Rasai Steponavičiūtei ir laborantei Laurai Jasiūnaitei už pagalbą atliekant ELISA tyrimus.

\section{DISTINCTIVE CHARACTERISTICS OF METABOLISM AND INFLAMMATION IN MEN WITH OBSTRUCTIVE SLEEP APNEA}

GUODA PILKAUSKAITE

DEPARTMENT OF PULMONOLOGY AND IMMUNOLOGY ACADEMY OF MEDICINE LUHS

Keywords: obsctructive sleep apnea, obesity, metabolic sindrome.

Summary. The aim, design and main results of the doctoral disertation defended by Guoda Pilkauskaite at the open session of the Medical Research Council of Medical Academy of Lithuanian University of Health Sciences on the 28th of August, 2014 are presented in this article.

Literatūros šatltiniai (iš viso 3) redakcijoje. 